\title{
A Duo 4-Plex Real Time PCR for Detection of Eight Tick-Borne Zoonoses in Kenya
}

\author{
Beth Mutai $^{1,2}$, Kariuki Njaanake2, Kimita Gathii ${ }^{1}$, Benson B. Estambale ${ }^{2,3}$, John N. Waitumbi ${ }^{1}$ \\ ${ }^{1}$ US Army Medical Research Directorate-Kenya, Kenya Medical Research Institute, Kisumu, Kenya \\ ${ }^{2}$ Department of Medical Microbiology, University of Nairobi, Nairobi, Kenya \\ ${ }^{3}$ Jaramogi Oginga Odinga University of Science and Technology, Kisumu, Kenya \\ Email: john.waitumbi@usamru-k.org
}

How to cite this paper: Mutai, B., Njaanake, K., Gathii, K., Estambale, B.B. and Waitumbi, J.N. (2019) A Duo 4-Plex Real Time PCR for Detection of Eight Tick-Borne Zoonoses in Kenya. Open Journal of Clinical Diagnostics, 9, 1-15.

https://doi.org/10.4236/ojcd.2019.91001

Received: December 20, 2018

Accepted: March 3, 2019

Published: March 6, 2019

Copyright (c) 2019 by author(s) and Scientific Research Publishing Inc. This work is licensed under the Creative Commons Attribution International License (CC BY 4.0).

http://creativecommons.org/licenses/by/4.0/

\begin{abstract}
Ticks harbor multiple pathogens, most of which can be transmitted to humans. The ensuing zoonoses display non-specific symptoms that make definitive diagnosis difficult. We report here the development and evaluation of multiplex real time polymerase chain reaction (qPCR) assays for eight tick-borne zoonoses (TBZ). The assays were organized in duo formats of 4-plex each. Format 1 was optimized for Anaplasma phagocytophilum, Coxiella burnetii, Borrelia burgdoferi and Ehrlichia chaffeensis. Format 2 was optimized for Rickettsia species (spp.), Bartonella spp., Borrelia spp. other than B. burgdoferi and Babesia spp. Synthetic plasmids were used to show that the assays can specifically detect all target sequences in the same reaction tube. Assays were assayed eight times to determine assay performance and the limit of detection was determined as the lowest plasmid concentration that was amplified for all the targets. Standard curves of threshold cycle $(\mathrm{Ct})$ versus copy numbers were generated and used to determine linearity and efficiency of the assays. Pairwise comparison of singleplex and multiplex assays was done using Bland-Altman plots. Prevalence was calculated as overall percentage of positive patients to each TBZ tested Assay 1 had a limit of detection of 2 copy numbers for all targets. Assay 2 was less sensitive and on average had a limit of detection of 18 gene copies. In replicate tests, both assays had intra-assay variation of less than two cycles. Multiplex assays performance was comparable to respective singleplex assays. Evaluation of 512 clinical samples collected between 2008 and 2016 from acute febrile illness patients attending hospitals in different counties in Kenya revealed a $20 \%$ prevalence of tick-borne pathogens comprising $B$. burgdorferi (6\%), non B. burgdorferi Borrelia spp. (3\%), C. burnetii (5\%), $A$. phagocytophilum (5\%), Rickettsia spp. (2\%), E. chaffeensis (0.8\%), Bartonella spp. (0.8\%), and Babesia spp. (0.4\%). The high analytical sensitivity suggests potential for the duo 4-plex qPCR for detection of common TBZ.
\end{abstract}




\section{Keywords}

Tick-Borne-Zoonoses, Multiplex Real Time PCR, Acute Febrile Illness

\section{Background}

Ticks carry microorganisms that can be transmitted between humans and animals. In humans, some of these pathogens cause acute febrile illness (AFI) and form the largest proportion of emerging zoonotic infections [1]. The common tick-borne zoonoses (TBZ) are Anaplasma phagocytophilum, Ehrlichia chaffeensis, Borrelia species (spp), Babesia spp., Bartonella spp., Crimean Congo Hemorrhagic Fever virus and Coxiella burnetii. Multiple pathogens can be harbored by a single tick and can then be transmitted to susceptible hosts [2] [3] [4]. Surveillance studies for TBZ in Kenya and in Africa are scanty and when performed, they have tended to focus on single pathogens. For example, rickettsiae surveillance in ticks in Kenya showed a wide distribution of tick vectors, with $23.3 \%$ rickettsia infection [5]. Other tick studies have shown presence of bacteria that cause rickettsioses, bartonellosis, ehrlichiosis, Q fever, Lyme disease and Babesia [5]-[10]. A recent review by Prasad et al., identified lack of multi-pathogen surveillance approaches as one of the factors limiting fever surveillance efforts [11]. In order to start to close these diagnostic gaps, multiplex qPCR assays that are relevant to the local disease situations will be needed.

Multiplexing capabilities of Taqman $\mathrm{qPCR}$ provide a rapid, cost effective and high-throughput method for multiple pathogen detection in a single tube assay format and has been used in multiple studies [12] [13] [14]. Commercial test kits available for diagnosis of TBZ exist in the market but are expensive and generally contain targets that may not be of local relevance. In this study, we developed two multiplex Taqman qPCR assays for detection of the following common TBZ: A. phagocytophilum, C. burnetii, B. burgdorferi, non B. burgdorferi, Borrelia, E. chaffeensis, Rickettsia spp., Bartonella spp. and Babesia spp.

\section{Material and Methods}

\subsection{Ethical Approval}

Blood specimens used in this study were collected under an ongoing surveillance protocol approved by the Scientific and Ethical Review Committee of Kenya Medical Research Institute (SSC \#1282) and the Human Subject Protection Branch (HSPB) of the Walter Reed Army Institute (WRAIR HSPB \#1402). Patients were recruited to the study after signing informed consent.

\subsection{Sources of DNA Samples for Assay Optimization}

To develop and validate qPCR for detection of TBZ, we used artificial linearized plasmids containing the gene sequences targeted by the primers and probes listed in Table 1 that were commercially synthesized by Genscript (NJ, USA). 
Table 1. Primers and probes used for the duo 4-plex qPCR for detection 8 Tick Borne Zoonoses.

\begin{tabular}{|c|c|c|c|c|c|}
\hline Target & Sequence of primer or probe $\left(5^{\prime}-3^{\prime}\right)$ & $\begin{array}{l}\text { Annealing } \\
\text { temperature } \\
\quad\left({ }^{\circ} \mathrm{C}\right)\end{array}$ & $\begin{array}{l}\text { Target } \\
\text { gene }\end{array}$ & $\begin{array}{l}\text { Amplicon } \\
\text { size } \\
\text { (base pairs) }\end{array}$ & Reference \\
\hline $\begin{array}{l}\text { Coxiella } \\
\text { burnetii }\end{array}$ & $\begin{array}{l}\text { Forward primer: AAAACGGATAAAAAGAGTCTGTGGTT } \\
\text { Reverse Primer-CCACACAAGCGCGATTCAT } \\
\text { Probe-[FAM]AAAGCACTCATTGAGCGCCGCG[MGB] }\end{array}$ & 60 & $\begin{array}{c}\text { IS1111 } \\
\text { transposase }\end{array}$ & 70 & {$[17]$} \\
\hline $\begin{array}{c}\text { Borrelia } \\
\text { burgdorferi }\end{array}$ & $\begin{array}{l}\text { Forward primer CGAGTCTTAAAAGGGCGATTTAGT } \\
\text { Reverse Primer-GCTTCAGCCTGGCCATAAATAG } \\
\text { Probe-[NED]AGATGTGGTAGACCCGAAGCCGAGTG[MGB] }\end{array}$ & 60 & $23 \mathrm{~S}$ rRNA & 75 & {$[12]$} \\
\hline $\begin{array}{l}\text { Anaplasma } \\
\text { phagocytophilum }\end{array}$ & $\begin{array}{l}\text { Forward primer: ATGGAAGGTAGTGTTGGTTATGGTATT } \\
\text { Reverse Primer: TTGGTCTTGAAGCGCTCGTA } \\
\text { Probe: [JOE]TGGTGCCAGGGTTGAGCTTGAGATTG[BHQ-1] }\end{array}$ & 60 & MSP2 & 77 & {$[12]$} \\
\hline $\begin{array}{l}\text { Ehrlichia } \\
\text { Chaffeensis }\end{array}$ & $\begin{array}{l}\text { Forward primer-GCGGCAAGCCTAACACATG } \\
\text { Reverse Primer-CCCGTCTGCCACTAACAATTATT } \\
\text { Probe-[CY-5]AGTCGAACGGACAATTGCTTATAACCTTTTGGT } \\
\text { [BBQ650] }\end{array}$ & 60 & $16 \mathrm{~S}$ rRNA & 81 & {$[18]$} \\
\hline Bartonella spp. & $\begin{array}{l}\text { Fwd primer-TGCTTCGACATCCACTGTACGTC } \\
\text { Rev Primer-CACCTGCTGCAATACATGCAAATG } \\
\text { Probe-[CY-3]TTGCAGGTTCATCAGGTGCTAATC[BHQ-2] }\end{array}$ & 60 & $\begin{array}{c}\text { Citrate } \\
\text { synthase }\end{array}$ & 200 & {$[22]$} \\
\hline Rickettsia spp. & $\begin{array}{l}\text { Fwd primer-ATGAATAAACAAGGKACNGGHACAC } \\
\text { Rev Primer-AAGTAATGCRCCTACACCTACTC } \\
\text { Probe-[FAM]CCGAATTGAGAACCAAGTAATGC[BHQ-1] }\end{array}$ & 60 & $\begin{array}{l}17 \mathrm{KDa} \\
\text { antigen }\end{array}$ & 96 & [19] \\
\hline Babesia spp. & $\begin{array}{l}\text { Forward primer-CAGCTTGACGGTAGGGTATTGG } \\
\text { Reverse Primer AGATGTGGTAGACCCGAAGCCGAGTG } \\
\text { Probe-[CY5]CGAGGCAGCAACGG[BBQ] }\end{array}$ & 56 & 18S rRNA & 62 & [20] \\
\hline Borrelia spp. & $\begin{array}{l}\text { Forward primer-GCTGAAGAGCTTGGAATGCAAC } \\
\text { Reverse Primer-GCTTCATCCTGATTTGCACCAAC } \\
\text { Probe-[JOE]CGCGATACACCAGCATCATTATCTGAATCACAATCGCG } \\
\text { [BHQ-1] }\end{array}$ & 56 & Flagellin & 110 & {$[21]$} \\
\hline
\end{tabular}

Full names of reporter and quencher fluorescent dyes on the probes: FAM: 6-carboxyfluorescein, CY5: cyanine-5, JOE: 6-carboxy-4',5'-dichloro-2', $7^{\prime}$-dimethoxyfluorescein, VIC: 2'-chloro-7'phenyl-1,4-dichloro-6-carboxy-fluorescein, NED: Naphthyl Ethylene Diamine, BHQ: Black Hole Quencher, BBQ: Black Berry Quencher, MGB: Minor Groove Binder.

Validated biological samples for the targets were not available, thus necessitating synthesizes of plasmids. Plasmid DNA were supplied lyophilized and reconstituted to $200 \mathrm{ng} / \mu \mathrm{L}$ in nuclease free water. Plasmid copy numbers were computed using an online calculator that takes into account the average base pair weight (650 Daltons) and the length of the plasmid and target insert in base pairs [15].

\subsection{Human DNA Samples}

Human whole blood samples $(n=512)$ that were collected between 2008 to 2016 
from different counties in Kenya under an acute febrile illness surveillance (AFI) study were used. The aim of the AFI study is to identify pathogens associated with febrile illnesses in Kenya. To participate in the study, the patients had to be one year and above, willing to provide informed consent (if 18 years and older or by guardian if less than 18 years), able to provide assent for children 13 years or older and be febrile (fever of $\geq 38^{\circ} \mathrm{C}$ ) without a readily diagnosable source after routine clinical evaluation. Whole blood specimen is taken and frozen in Liquid Nitrogen dry shippers and shipped to the laboratory for testing.

\subsection{Validation of the qPCR Assays Using Plasmids}

The study aimed to develop and validate multiplex qPCR assays for detection of 8 TBZ following the guidelines for the Standards for Reporting Diagnostic Accuracy [16].

Singleplex assay optimization: The amplification reactions were performed on Applied Biosystems 7500 fast Real time PCR system in a total of $10 \mu \mathrm{L}$ reaction that contained $5 \mu \mathrm{L}$ of Sensifast probe Lo-ROX PCR master mix (Bioline, CA, USA), $0.5 \mu \mathrm{M}$ of each forward and reverse primers, $0.4 \mu \mathrm{M}$ of the probe and $3.0 \mu \mathrm{L}$ of plasmid $\left(6.15 \times 10^{6}\right.$ copies $\left./ \mu \mathrm{L}\right)$ and nuclease-free water. Except for Bartonella genus, all other primers and probes were selected from published assays and only those with data on specificity [12] [17] [18] [19] [20] [21]. For Bartonella, the primers and probe used were redesigned to target a short region (200 bp) of the citrate synthase gene using primer express software (Applied Biosystems, CA, USA) from a published conventional PCR assay [22]. The specificity of all primers and probes was tested by homology searches in the NCBI nucleotide database [23]. Probes were labeled at the 5' end with a fluorescent reporter dye and an appropriate non fluorescent quencher at the 3 ' end. Reporter dyes combinations were selected to allow multiplexing of four targets in a ABI 7500 fast Real-Time PCR System (Applied Biosystems, CA, USA). Primers and probes used for the assays are listed in Table 1.

Duo 4 plex assay optimization: Following the initial optimization of singleplex assays, the primers and probes were pooled in a duo 4-plex assay. The $5^{\text {th }}$ channel of the 7500 fast Real time PCR machine was reserved for the ROX reference dye. The reaction mix for assay one was optimized to detect $C$. burnetii, A. phagocytophilum, B. burgdorferii and E. chaffeensis at the following cycling conditions: a $50^{\circ} \mathrm{C}$ hold for 2 minutes, $95^{\circ} \mathrm{C}$ initial denaturation for 10 minutes followed by 45 cycles of $95^{\circ} \mathrm{C}$ denaturation for 15 seconds and $60^{\circ} \mathrm{C}$ annealing for 1 minute. Assay two was optimized to detect Rickettsia spp., Babesia spp., Bartonella spp. and other Borrelia spp. at the following cycling conditions: $50^{\circ} \mathrm{C}$ hold for 2 minutes, $95^{\circ} \mathrm{C}$ denaturation for 10 minutes followed by 45 cycles of $95^{\circ} \mathrm{C}$ denaturation for 15 seconds and $56^{\circ} \mathrm{C}$ annealing for 1 minute. After the run, each target result was analyzed separately to set appropriate threshold level which is the amplification cycle where fluorescence increases significantly above the background fluorescence. For both assays, qPCR was performed in a total of 
$10 \mu \mathrm{L}$ reaction volume using $2 \times$ Sensifast probe Lo-ROX PCR master mix (Bioline, CA, USA) that contained $5 \mu \mathrm{L}$ of master mix, $0.5 \mu \mathrm{M}$ of each primer, $0.4 \mu \mathrm{M}$ of each probe and $3.0 \mu \mathrm{L}$ of plasmid, nuclease-free water was added to a final volume of $10 \mu \mathrm{L}$. For each assay a no template control was included. A reaction was scored positive for any of the targets if there was amplification resulting to fluorescence that generated a threshold cycle (ct) of less than 40 .

\subsection{Determining Assay Sensitivity for Singleplex and 4-Plex Assays}

Each plasmid was diluted by 10 fold over a range of $6.15 \times 10^{6}$ to $6.15 \times 10^{-1}$ copies $/ \mu \mathrm{L}$. Each concentration was tested eight times with both singleplex and 4-plex assays. For 4-plex assays, plasmids were mixed together at a concentration of $6.15 \times 10^{6} \mathrm{copies} / \mu \mathrm{L}$ each to mimic co-infections, and then diluted in 10 -fold increments. Limit of detection (LOD) for each assay was determined as the lowest plasmid concentration that was amplified for all targets. LOD was then reported as equivalent pathogen detectable by the assay depending on copy number of each target gene present in its genome. B. burgdorferi has 2 copies of $23 \mathrm{~S}$ rRNA gene [24], A. phagocytophilum has 1 copy of the MSP2 gene [25], E. chaffeensis has 1 copy of the 16S rRNA gene [18], Coxiella burnetii has 2 to 20 copies of the IS111 gene [26], Rickettsia has 1copy of $17 \mathrm{kDa}$ gene [27], Borrelia has 1 copy of the flagelin gene [28], Bartonella has 1 copy of citrate synthase gene (gltA) [29] and Babesia has 2 copies of $18 \mathrm{~S}$ rRNA gene [30]. Sensitivity of co-amplifications was also tested using lowest concentrations $\left(6.15 \times 10^{-1}\right.$ copies $\left./ \mu \mathrm{L}\right)$ of each target in presence of high concentrations $\left(6.15 \times 10^{6}\right.$ copies $\left./ \mu \mathrm{L}\right)$ of othernon-targets.

\subsection{Determining Efficiency, Linearity and Precision of Singleplex and 4-Plex Assays}

To determine linearity and efficiency of the assays, standard curves of threshold cycle $(\mathrm{Ct})$ versus copy numbers were generated over the $6.15 \times 10^{6}$ to $6.15 \times 10^{-1}$ copies/ $\mu \mathrm{L}$ test range. qPCR reaction efficiency was calculated from the slope of the standard curve according to the equation $\log E=10^{\left(-1 / \text { llope }^{-1}\right.}$ [31]. To determine the reproducibility (precision) of the assays, three concentrations (6.15 $\times 10^{6}, 6.15 \times 10^{3}$ and $6.15 \times 10^{-1}$ copies $/ \mu \mathrm{L}$ ) of plasmid were assayed in triplicates five times on separate days. Coefficient of variation (CV) and Standard Deviation (SD) were calculated at each concentration for all targets.

\subsection{Pairwise Comparison between Singleplex and Multiplex Assays}

Bland-Altman analysis was used to depict the magnitude of disagreement between singleplex and multiplex assays. In Bland-Altman analysis, the $\mathrm{Ct}$ value difference $(\Delta \mathrm{Ct})$ between singleplex and multiplex assays are plotted against the mean of the $\mathrm{Ct}$ values of the two assays [32]. Pairwise comparison was performed using $\mathrm{Ct}$ values from singleplex and 4-plex assays at various dilutions. 


\subsection{Use of Duo 4-Plex qPCR for Detection of Tick Borne Zoonoses in Human Samples}

The duo 4-plex qPCR was then used to screen 512 blood samples randomly selected using Microsoft Excel 2007 from a repository of over 7000 clinical samples. Nucleic acids were extracted from $200 \mu \mathrm{L}$ whole blood using ZR-Duet DNA/RNA mini prep kit (ZYMO Research, CA USA) and eluted in $50 \mu \mathrm{L}$. Three microliters of nucleic acid was used as template in each of the assays.

\subsection{Data Analysis}

To determine the linearity, precision and efficiency of the assays, standard curves of threshold cycle versus copy numbers were generated using an Applied Biosystems real time PCR software version 2.3. Graphpad Prism version 5 was used for prevalence calculations, plotting graphs and Bland-Altman Pairwise comparison.

\section{Results}

\subsection{Performance of Duo 4-Plex qPCR Assays}

Assay specificity. The primer and probe specificities were first evaluated in silico on the NCBI Blast [33]. No matches to the primer sequences were found other than those corresponding to the target genes. To validate the in silico results, the specificity of the primers and probes were evaluated by qPCR in the presence targeted and non-target plasmids. As shown in Table 2, there was no cross-amplification or interference in product formation (Ct values were fairly similar between corresponding singleplex and 4-plex targets). High target plasmid concentration did not affect detection level of the other targets.

Table 2. Target specific with no cross amplification for 4-plex and mono-plex assays.

\begin{tabular}{|c|c|c|c|c|}
\hline \multicolumn{5}{|c|}{ Assay one mean $\mathrm{Ct}$ values with mixed targets } \\
\hline $\begin{array}{l}\text { Target at } 6.15 \times 10^{6} \\
\text { plasmid copies per } \mu \mathrm{L}\end{array}$ & Coxiella & A. phagocytophilum & B. burgdorferi & E. chaffeensis \\
\hline Coxiella & $12.83(12.35)$ & - & - & - \\
\hline A. phagocytophilum & - & $13.03(13.13)$ & - & - \\
\hline B. burgdorferi & - & - & $11.69(12.96)$ & - \\
\hline E. chaffeensis & - & - & - & $12.89(12.1)$ \\
\hline \multicolumn{5}{|c|}{ Assay two mean $\mathrm{Ct}$ values with mixed target } \\
\hline $\begin{array}{l}\text { Target at } 6.15 \times 10^{6} \\
\text { plasmid copies per } \mu \mathrm{L}\end{array}$ & Rickettsia & $\begin{array}{l}\text { Other non } \\
\text { burgdorferi Borrelia }\end{array}$ & Bartonella & Babesia \\
\hline Rickettsia & $11.13(10.33)$ & - & - & - \\
\hline Other Borrelia & - & $10.39(10.88)$ & - & - \\
\hline Bartonella & - & - & $12.08(12.1)$ & - \\
\hline Babesia & - & - & - & $24.20(24.53)$ \\
\hline
\end{tabular}

-Target not detected by the assay. 
Assay sensitivity and dynamic range: As shown in Figure 1, in 8 repeat experiments, all targets in assay one were detected between $6.15 \times 10^{6}$ to $6.15 \times 10^{1}$ copies/ $\mu \mathrm{L}$ corresponding to $\mathrm{Ct}$ values of 12 to 40 and linear range for this assay was $6.15 \times 10^{6}$ to 6.15 copies $/ \mu \mathrm{L}$ (Figure 1 ). For assay two in 8 repeat experiments all targets were detected between $6.15 \times 10^{6}$ to $6.15 \times 10^{0}$ copies $/ \mu \mathrm{L}$ corresponding to Ct values of 11 to 36 for Rickettsia and Borrelia, 11 to 38 for Bartonella and 23 to 37 for Babesia. The linear range for assay two varied per target with Rickettsia and Borrelia ranging between $6.15 \times 10^{6}$ to 6.15 copies $/ \mu \mathrm{L}, 6.15 \times$ $10^{5}$ to 6.15 copies $/ \mu \mathrm{L}$ for Bartonella and $6.15 \times 10^{3}$ to 0.615 copies $/ \mu \mathrm{L}$, for Babesia (Figure 2).
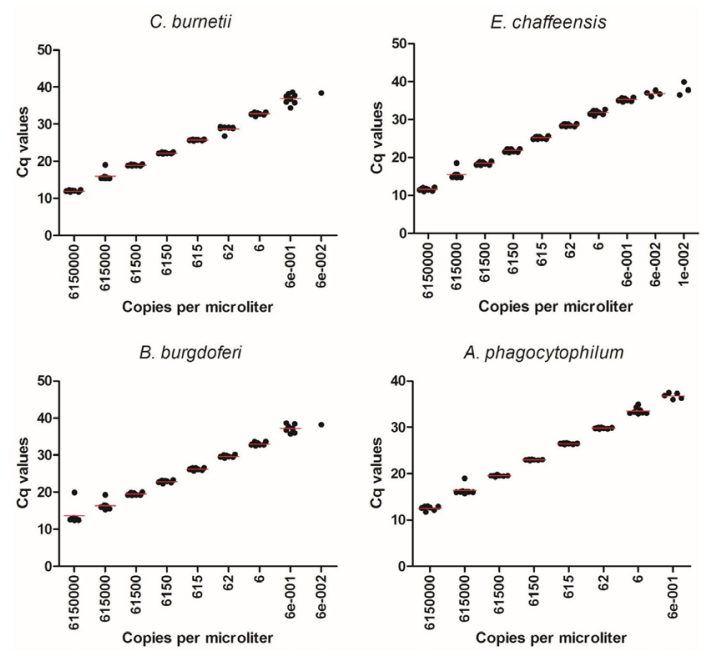

Figure 1. Ct values plotted against copy numbers of serially diluted plasmids for the 4-plex assay one. In 8 repeat experiments, C. burnetii, E. chaffeensis, B. burgdorferi and A. phagocytophilum were detected between $6.15 \times 10^{6}$ to $6.15 \times 10^{-1}$ copies $/ \mu \mathrm{L}$. Red line indicates the mean ct for each dilution.
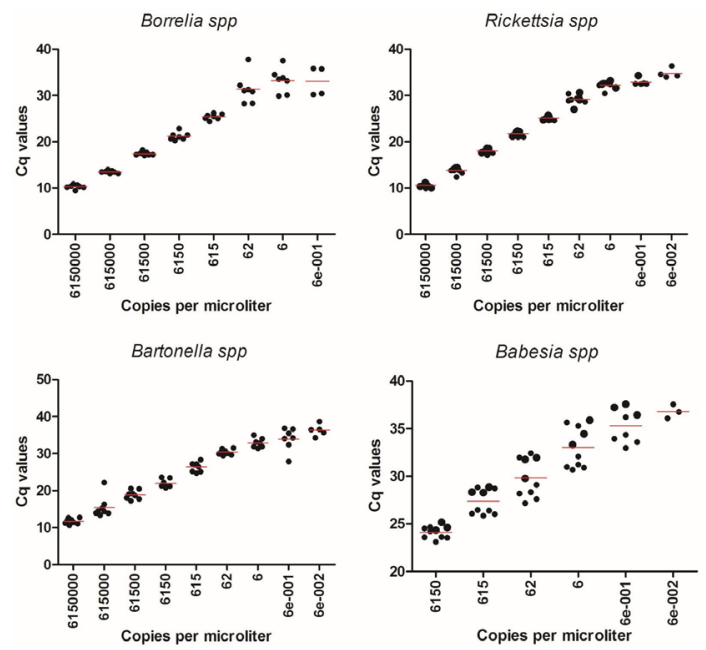

Figure 2. Ct values plotted against Copies per microliter of serially diluted plasmid DNA with 4-plex assay two. In 8 repeat experiments, Rickettsia and Borrelia was $6.15 \times 10^{6}$ to 6.15 copies $/ \mu \mathrm{L}, 6.15 \times 10^{5}$ to 6.15 copies $/ \mu \mathrm{L}$ for Bartonella and $6.15 \times 10^{3}$ to 0.615 copies $/ \mu \mathrm{L}$, for Babesia. Red line indicates the mean $\mathrm{Ct}$ value at each dilution. 
Efficiency, linearity and precision of optimized multiplex assays. As shown in Table 3, the duo 4-plex assays had strong linear correlation to input DNA template. The assay's efficiencies ranged from 94 to 100 with correlation coefficient $\left(R^{2}\right)$ values of 0.99 to 0.999 indicating high linearity (Table 3). All assays had a standard deviation of one cycle or below indicating high precision for all targets at different concentrations. Coefficients of variation for replicate $\mathrm{Ct}$ values at each concentration for all targets were below 0.1 with a median value of 0.01 for assay one and 0.02 for assay two for all the concentration tested.

\subsection{Comparison of Multiplex and Singleplex qPCR Assays}

Bland-Altman analysis was used to depict the magnitude of disagreement between multiplex and singleplex assays. The difference in $\mathrm{Ct}$ values $(\Delta \mathrm{Ct})$ between multiplex and singleplex assays were plotted against the mean of the $\mathrm{Ct}$ values of the serially diluted plasmid for multiplex and singleplex assays. As shown in Figure 3, the $\Delta \mathrm{Ct}$ for the assays were within a range of -1.7 to 0.8 for Coxiella,
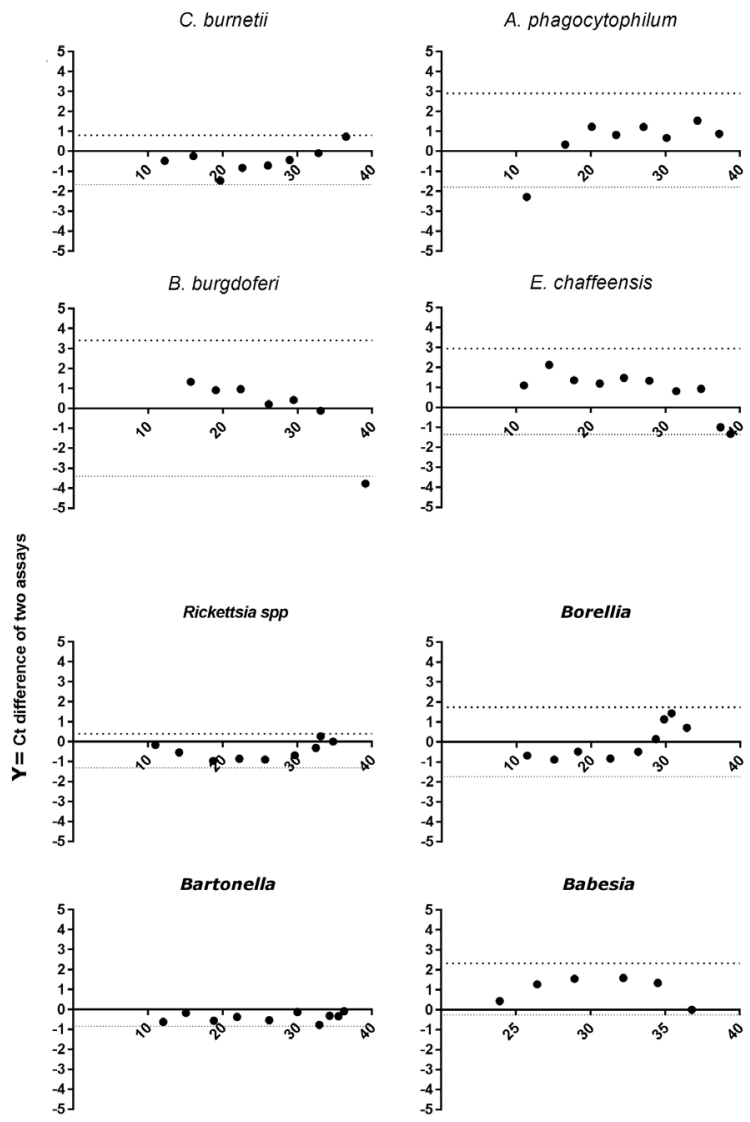

$\mathbf{X}=$ Average $\mathrm{Ct}$ values

Figure 3. Bland-Altman plots showing differences between singleplex and multiplex assays. Ct values $(\Delta \mathrm{Ct})$ for multiplex and singleplex assays are plotted against the mean of the $\mathrm{Ct}$ values of the serially diluted plasmid for multiplex and singleplex assays (dots) with representation of the limits of agreement (dotted line) within $-1.96 \mathrm{SD}$ to $+1.96 \mathrm{SD}$. The reference line (solid line) on the plot indicate the ideal zero difference ( $\mathrm{x}$ axis $=$ average $\mathrm{Ct}$ values and $\mathrm{y}$ axis $=\mathrm{Ct}$ differences of the two assays). 
Table 3. Duo 4-plex qPCR showing amplification linearity and efficiency for target pathogens.

\begin{tabular}{ccccc}
\hline Assay & Target pathogen & Standard curve Slope & PCR Efficiency & $\mathbf{R}^{2}$ \\
\hline \multirow{3}{*}{ Panel one } & C. burnetii & -3.442 & 95.96 & 0.99 \\
& A. phagocytophilum & -3.468 & 94.23 & 0.998 \\
& B. burgdorferi & -3.464 & 94.40 & 0.998 \\
& E. chaffeensis & -3.436 & 95.46 & 0.998 \\
\multirow{3}{*}{ Panel two } & Rickettsia & -3.736 & 95.00 & 0.997 \\
& Other Borrelia & -3.462 & 94.00 & 0.996 \\
& Bartonella & -3.678 & 97.00 & 0.995 \\
& Babesia & -2.595 & 100.00 & 0.997 \\
\hline
\end{tabular}

-1.8 to 2.9 for A. phagocytophilum, 03 to 3.4 for B. burgdorferi, -1.3 to 2.9 for E. chaffeensis, -1.3 to 0.4 for Rickettsia, -0.8 to 0.1 for Bartonella, -0.3 to 2.3 for Babesia and -1.7 to 1.7 for other Borrelia. Mean $\Delta \mathrm{Ct}$ are very close to zero indicating small differences between the multiplex and singleplex assays.

\subsection{Use of Duo 4-Plex qPCR in Clinical Specimens}

A total of 512 blood samples that were collected from patients with acute febrile illness were tested for TBZ using the duo 4-plex qPCR. A total of 512 whole blood samples collected between the period of February 2008 and December 2016 were tested for presence of TBZ using the duo 4-plex qPCR. Of 512, 194 (37.9\%) were males while 208 (40.6\%) were females.. The age ranged from 1 to 75 years with a median of 35 years.

Of the 512 samples, $102(20 \%)$ had at least one of the 8 tick-borne pathogens: C. burnetii (5\%), A. phagocytophilum (6\%), E. chaffeensis (0.8\%), B. burgdorferi (7\%), non B. burgdorferi Borrelia spp. (4\%), Babesia spp. (0.4\%), Rickettsia spp. (2\%), and Bartonella spp. (0.8\%). 86 of the 102 specimens (84.3\%) had mono-infections and $16(15.7 \%)$ had two or more TBZ pathogens present of which $14(13.7 \%)$ had two infections and 1 specimen $(<1 \%)$ had three or four targets as shown in Table 4.

\section{Discussion}

Worldwide ticks transmit the widest diversity of pathogens to humans and domestic animals, compared to other vectors. As a consequence, TBZ form the largest proportion of emerging infections [34] [35]. In Kenya, many studies have reported presence of Rickettsia, Borrelia, Coxiella, Ehrlichia, Babesia, Anaplasma and Crimean-Congo Hemorrhagic fever virus [5] [7] [8] [9] [36] [37] [38]. Although these reports evaluated the presence of these pathogens in different studies, they serve as pointers to the variety of tick borne pathogens in Kenya. Lack of multi-pathogen diagnostics has been cited as a major limitation to surveillance efforts in Africa that has led to poor epidemiological information and a 
Table 4. Combinations of TBZ pathogens detected in clinical samples.

\begin{tabular}{cc}
\hline Pathogen associations & Number of TBZ infections \\
\hline Rickettsia spp. + Coxiella & 1 \\
Rickettsia spp. + B. Burgdorferi & 1 \\
Rickettsia + Other Borrelia spp. & 1 \\
Coxiella + E. chaffeensis & 1 \\
Coxiella + B. burgdorferi & 1 \\
A. phagocytophilum + Bartonella spp. & 1 \\
A. phagocytophilum + other Borrelia & 1 \\
A. phagocytophilum + B. burgdorferi & 2 \\
B. burgdorferi + Babesia spp. & 1 \\
B. burgdorferi + Bartonella spp. & 1 \\
B. burgdorferi + other Borrelia spp. & 2 \\
Babesia spp. + other Borrelia spp. & 1 \\
A. phagocytophilum + Bartonella spp. + Borrelia spp. & 1 \\
\hline Coxiella + A. phagocytophilum + B. burgdorferi + Borrelia spp. & 1 \\
\hline
\end{tabular}

narrow list of differential diagnosis [11]. As has been reported earlier [39] [40] assay multiplexing simplifies workflow, is amenable to high throughput, conserves specimen volumes, reduces reagent costs and person time. In the current study, multiplex assays were designed for $8 \mathrm{TBZ}$ pathogens and thereafter used to evaluate their presence in clinical samples obtained from febrile illness patients.

Real time PCR instruments have limited number of acquisition channels which limit the number of targets that can be multiplexed in an assay. Therefore, for the 8 target pathogens in this report, the 5 channel 7500 Fast Real time PCR system (Applied Biosystems. Foster City CA USA) could only accommodate 4 targets at a time. The duo 4-plex assays performed as well as the singleplex assays qualifying them for simultaneous detection of four TBZ pathogens each in a sample which reduces time to result (Table 2 and Figure 3).

Many of the tick-borne bacteria targeted by the duo 4-plex assays do not generate high bacteremia and have fastidious growth requirement in culture, thus making convectional diagnostic methods less sensitive and time consuming [41]. An assay that can detect low copies of bacterial DNA in samples during early stage of the infections is critical for early diagnosis and targeted treatment [42]. Our duo 4-plex qPCR assays have a limit of detection of 1.8 gene copies for assay one and 18.45 gene copies for assay two (Figure 1 and Figure 2). The optimized assays are robust with high linearity and efficiency and they can be used for quantification of TBZ pathogens (Table 3).

The high analytical sensitivity of the assays demonstrated the potential for use of the duo 4-plex qPCR in detection of the 8 common TBZ. To validate these assays, we evaluated 512 clinical blood samples collected from febrile patients 
attending hospitals in different regions of Kenya. A 20\% prevalence of tick-borne pathogens comprising B. burgdorferi (7\%), C. burnetii (5\%), A. phagocytophilum (6\%), non B. burgdorferi Borrelia spp. (4\%), Rickettsia (2\%), E. chaffeensis (0.8\%), Bartonella spp. (0.8\%), and Babesia spp. (0.4\%) was detected. Majority were mono-infections (84.3\%) and declined progressively to $13.7 \%$ for dual infections, and $<1 \%$ for three or four targets (Table 4 ). As has been pointed out, risk of co-infections is dependent on the prevalence of the pathogens in the host tick [43] or antagonistic effect of one bacterium on another that may inhibit transmission of a second agent [44].

One limitation of this study is the lack of confirmed positive or negative clinical samples for evaluation of analytical sensitivity of the assays. Because clinical samples have a complex matrix, analytical sensitivities based on artificial plasmids could differ from those of vectors, patients or host animals.

As far as we are aware, the tick borne pathogens identified in the study patients who had febrile illnesses are neither routinely diagnosed in Kenyan public hospitals nor are they in the differential diagnosis list of clinicians.

In conclusion, the duo 4-plex qPCR assays that were developed and used in this study identified a variety of tick borne pathogens in patient with febrile illnesses. Additional work to link pathogens detected and clinical description is needed to move such diagnosis from the research environment to hospitals. It is recommended that TBZ be included in differential diagnosis of AFI and that the laboratory capability for their diagnosis be enhanced.

\section{Acknowledgements}

Funding for this study was obtained from the Armed Forces Health Surveillance Branch (AFHSB) and GEIS (Global Emerging Infections Surveillance and Response) Section, Global Emerging Infectious Surveillance and Response (GEIS).

\section{Conflicts of Interest}

The authors declare that they have no competing interests.

\section{Ethical Statement}

The study protocol was approved by the Scientific and Ethical Review Committee of Kenya Medical Research Institute (SSC \#1282) and the Human Subject Protection Branch (HSPB) of the Walter Reed Army Institute (WRAIR HSPB \#1402).

\section{Disclaimer}

Material has been reviewed by the Walter Reed Army Institute of Research. There is no objection to its presentation and/or publication. The opinions or assertions contained herein are the private views of the author, and are not to be construed as official, or as reflecting true views of the Department of the Army or the Department of Defense. The investigators have adhered to the policies for 
protection of human subjects as prescribed in AR 70-25.

\section{References}

[1] Sonenshine, D.E. (1992) Biology of Ticks. 1st Edition, Oxford University Press, Oxford.

[2] Coipan, E.C., Jahfari, S., Fonville, M., Maassen, C.B., van der Giessen, J., Takken, W., et al. (2013) Spatiotemporal Dynamics of Emerging Pathogens in Questing Ixodes Ricinus. Frontiers in Cellular and Infection Microbiology, 3, 36. https://doi.org/10.3389/fcimb.2013.00036

[3] Moutailler, S., Valiente Moro, C., Vaumourin, E., Michelet, L., Tran, F.H., Devillers, E., et al. (2016) Co-Infection of Ticks: The Rule Rather than the Exception. PLoS Neglected Tropical Diseases, 10, e0004539. https://doi.org/10.1371/journal.pntd.0004539

[4] Raileanu, C., Moutailler, S., Pavel, I., Porea, D., Mihalca, A.D., Savuta, G., et al. (2017) Borrelia Diversity and Co-Infection with Other Tick Borne Pathogens in Ticks. Frontiers in Cellular and Infection Microbiology, 7, 36. https://doi.org/10.3389/fcimb.2017.00036

[5] Mutai, B.K., Wainaina, J.M., Magiri, C.G., Nganga, J.K., Ithondeka, P.M., Njagi, O.N., et al. (2013) Zoonotic Surveillance for Rickettsiae in Domestic Animals in Kenya. Vector-Borne and Zoonotic Diseases, 13, 360-366. https://doi.org/10.1089/vbz.2012.0977

[6] Halliday, J.E.B., Knobel, D.L., Agwanda, B., Bai, Y., Breiman, R.F., Cleaveland, S., et al. (2015) Prevalence and Diversity of Small Mammal-Associated Bartonella Species in Rural and Urban Kenya. PLoS Neglected Tropical Diseases, e0003608.

[7] Jowi, J.O. and Gathua, S.N. (2005) Lyme Disease: Report of Two Cases. East African Medical Journal, 82, 267-269. https://doi.org/10.4314/eamj.v82i5.9318

[8] Richards, A.L., Jiang, J., Omulo, S., Dare, R., Abdirahman, K., Ali, A., et al. (2010) Human Infection with Rickettsia felis, Kenya. Emerging Infectious Diseases, 16, 1081-1086. https://doi.org/10.3201/eid1607.091885

[9] Njiiri, N.E., deC. Bronsvoort, B.M., Collins, N.E., Steyn, H.C., Troskie, M., Vorster, I., et al. (2015) The Epidemiology of Tick-Borne Haemoparasites as Determined by the Reverse Line Blot Hybridization Assay in an Intensively Studied Cohort of Calves in Western Kenya. Veterinary Parasitology, 210, 69-76.

https://doi.org/10.1016/j.vetpar.2015.02.020

[10] Adjou Moumouni, P.F., Aboge, G.O., Terkawi, M.A., Masatani, T., Cao, S., Kamyingkird, K., et al. (2015) Molecular Detection and Characterization of Babesia bovis, Babesia bigemina, Theileria Species and Anaplasma marginale Isolated from Cattle in Kenya. Parasites and Vectors, 8, 496. https://doi.org/10.1186/s13071-015-1106-9

[11] Prasad, N., Murdoch, D.R., Reyburn, H. and Crump, J.A. (2015) Etiology of Severe Febrile Illness in Low- and Middle-Income Countries: A Systematic Review. PLoS ONE, 10, e0127962. https://doi.org/10.1371/journal.pone.0127962

[12] Courtney, J.W., Kostelnik, L.M., Zeidner, N.S. and Massung, R.F. (2004) Multiplex Real-Time PCR for Detection of Anaplasma phagocytophilum and Borrelia burgdorferi Multiplex Real-Time PCR for Detection of Anaplasma phagocytophilum and Borrelia burgdorferi. Journal of Clinical Microbiology, 42, 3164-3168. https://doi.org/10.1128/JCM.42.7.3164-3168.2004

[13] Pripuzova, N., Wang, R., Tsai, S., Li, B., Hung, G.C., Ptak, R.G., et al. (2012) Devel- 
opment of Real-Time PCR Array for Simultaneous Detection of Eight Human Blood-Borne Viral Pathogens. PLoS ONE, 7, e43246.

https://doi.org/10.1371/journal.pone.0043246

[14] Gowin, E., Bartkowska-Śniatkowska, A., Jończyk-Potoczna, K., Wysocka Leszczyńska, J., Bobkowski, W., Fichna, P., et al. (2017) Assessment of the Usefulness of Multiplex Real-Time PCR Tests in the Diagnostic and Therapeutic Process of Pneumonia in Hospitalized Children: A Single-Center Experience. BioMed Research International, 2017, Article ID: 8037963. https://doi.org/10.1155/2017/8037963

[15] Staroscik, A. (2004) Calculator for Determining the Number of Copies of a Template. http://cels.uri.edu/gsc/cndna.html

[16] Cohen, J.F., Korevaar, D.A., Altman, D.G., Bruns, D.E., Gatsonis, C.A., Hooft, L., et al. (2016) STARD 2015 Guidelines for Reporting Diagnostic Accuracy Studies: Explanation and Elaboration. BMJ Open, 6, e012799.

https://doi.org/10.1136/bmjopen-2016-012799

[17] Schneeberger, P.M., Hermans, M.H.A., Van Hannen, E.J., Schellekens, J.J.A., Leenders, A.C.A.P. and Wever, P.C. (2010) Real-Time PCR with Serum Samples Is Indispensable for Early Diagnosis of Acute Q Fever. Clinical and Vaccine Immunology, 17, 286-290. https://doi.org/10.1128/CVI.00454-09

[18] Loftis, A.D., Massung, R.F. and Levin, M.L. (2003) Quantitative Real-Time PCR Assay for Detection of Ehrlichia chaffeensis. Journal of Clinical Microbiology, 41, 3870-3872. https://doi.org/10.1128/JCM.41.8.3870-3872.2003

[19] Jiang, J., Stromdahl, E.Y. and Richards, A.L. (2012) Detection of Rickettsia parkeri and Candidatus Rickettsia Andeanae in Amblyomma maculatum Gulf Coast Ticks Collected from Humans in the United States. Vector-Borne and Zoonotic Diseases, 12, 175-182. https://doi.org/10.1089/vbz.2011.0614

[20] Radzijevskaja, J., Paulauskas, A. and Rosef, O. (2008) Prevalence of Anaplasma phagocytophilum and Babesia divergens in Ixodes ricinus Ticks from Lithuania and Norway. International Journal of Medical Microbiology, 298, 218-221. https://doi.org/10.1016/j.ijmm.2008.01.008

[21] Jiang, J., Temenak, J.J. and Richards, A.L. (2003) Real-Time PCR Duplex Assay for Rickettsia prowazekii and Borrelia recurrentis. Annals of the New York Academy of Sciences, 990, 302-310. https://doi.org/10.1111/j.1749-6632.2003.tb07380.x

[22] Billeter, S.A., Gundi, V.A.K.B., Rood, M.P. and Kosoy, M.Y. (2011) Molecular Detection and Identification of Bartonella Species in Xenopsylla cheopis Fleas (Siphonaptera: Pulicidae) Collected from Rattus norvegicus Rats in Los Angeles, California. Applied and Environmental Microbiology, 77, 7850-7852. https://doi.org/10.1128/AEM.06012-11

[23] Clark, K., Karsch-Mizrachi, I., Lipman, D.J., Ostell, J. and Sayers, E.W. (2016) GenBank. Nucleic Acids Research, 44, D67-D72. https://doi.org/10.1093/nar/gkv1276

[24] Schwartz, J.J., Gazumyan, A. and Schwartz, I. (1992) rRNA Gene Organization in the Lyme Disease Spirochete, Borrelia burgdorferi. Journal of Bacteriology, 174, 3757-3765. https://doi.org/10.1128/jb.174.11.3757-3765.1992

[25] Lin, Q., Rikihisa, Y., Felek, S., Wang, X., Massung, R.F. and Woldehiwet, Z. (2004) Anaplasma phagocytophilum Has a Functional msp2 Gene That Is Distinct from p44. Infection and Immunity, 72, 3883-3889.

https://doi.org/10.1128/IAI.72.7.3883-3889.2004

[26] Seshadri, R., Paulsen, I.T., Eisen, J.A., Read, T.D., Nelson, K.E., Nelson, W.C., et al. (2003) Complete Genome Sequence of the Q-Fever Pathogen Coxiella burnetii. Proceedings of the National Academy of Sciences of the United States, 100, 
5455-5460. https://doi.org/10.1073/pnas.0931379100

[27] Reif, K.E., Stout, R.W., Henry, G.C., Foil, L.D. and Macaluso, K.R. (2008) Prevalence and Infection Load Dynamics of Rickettsia felis in Actively Feeding Cat Fleas. PLoS ONE, 3, e2805. https://doi.org/10.1371/journal.pone.0002805

[28] Wallich, R., Moter, S.E., Simon, M.M., Ebnet, K., Heiberger, A. and Kramer, M.D. (1990) The Borrelia burgdorferi Flagellum-Associated 41-Kilodalton Antigen (Flagellin): Molecular Cloning, Expression, and Amplification of the Gene. Infection and Immunity, 58, 1711-1719.

[29] Guy, L., Nystedt, B., Toft, C., Zaremba-Niedzwiedzka, K., Berglund, E.C., Granberg, F., et al. (2013) A Gene Transfer Agent and a Dynamic Repertoire of Secretion Systems Hold the Keys to the Explosive Radiation of the Emerging Pathogen Bartonella. PLoS Genetics, 9, e1003393. https://doi.org/10.1371/journal.pgen.1003393

[30] Stańczak, J., Cieniuch, S., Lass, A., Biernat, B. and Racewicz, M. (2015) Detection and Quantification of Anaplasma phagocytophilum and Babesia spp. in Ixodes ricinus Ticks from Urban and Rural Environment, Northern Poland, by Real-Time Polymerase Chain Reaction. Experimental and Applied Acarology, 66, 63-81. https://doi.org/10.1007/s10493-015-9887-2

[31] Ian, M. (2007) Real-Time PCR in Microbiology: From Diagnosis to Characterization. Caister Academic Press, Poole.

[32] Altman, D.G. and Bland, J.M. (1983) Measurement in Medicine: The Analysis of Method Comparison Studies. The Statistician, 32, 307. https://doi.org/10.2307/2987937

[33] Altschul, S.F., Gish, W., Miller, W., Myers, E.W. and Lipman, D.J. (1990) Basic Local Alignment Search Tool. Journal of Molecular Biology, 215, 403-410. https://doi.org/10.1016/S0022-2836(05)80360-2

[34] Parola, P. and Raoult, D. (2001) Molecular Tools in the Epidemiology of Tick-Borne Bacterial Diseases. Annales de biologie Clinique, 59, 177-182.

[35] Parola, P. and Raoult, D. (2001) Ticks and Tickborne Bacterial Diseases in Humans: An Emerging Infectious Threat. Clinical Infectious Diseases, 32, 897-928. https://doi.org/10.1086/319347

[36] Kimita, G., Mutai, B., Nyanjom, S.G., Wamunyokoli, F. and Waitumbi, J. (2016) Phylogenetic Variants of Rickettsia africae, and Incidental Identification of "Candidatus Rickettsia Moyalensis” in Kenya. PLOS Neglected Tropical Diseases, 10, e0004788. https://doi.org/10.1371/journal.pntd.0004788

[37] Dunster, L., Dunster, M., Ofula, V., Beti, D., Kazooba-Voskamp, F., Burt, F., et al. (2002) First Documentation of Human Crimean-Congo Hemorrhagic Fever, Kenya. Emerging Infectious Diseases, 1005-1006. https://doi.org/10.3201/eid0809.010510

[38] Kitaa, J.M.A., Mulei, C.M., Mande, J.D. and Wabacha, J. (2014) A Retrospective Study of Canine Ehrlichiosis in Kenya. International Journal of Veterinary Science and Medicine, 3, 122-124.

[39] Wang, H.-Y., Kim, S., Kim, J., Park, S.-D., Uh, Y. and Lee, H. (2014) Multiplex Real-Time PCR Assay for Rapid Detection of Methicillin-Resistant Staphylococci Directly from Positive Blood Cultures. Journal of Clinical Microbiology, 52, 1911-1920. https://doi.org/10.1128/JCM.00389-14

[40] Yu, D., Chen, Y., Wu, S., Wang, B., Tang, Y.W. and Li, L. (2012) Simultaneous Detection and Differentiation of Human Papillomavirus Genotypes 6, 11, 16 and 18 by AllGlo Quadruplex Quantitative PCR. PLoS ONE, 7, e48972.

https://doi.org/10.1371/journal.pone.0048972 
[41] Fenollar, F. and Raoult, D. (2007) Molecular Diagnosis of Bloodstream Infections Caused by Non-Cultivable Bacteria. International Journal of Antimicrobial Agents, 30, 7-15. https://doi.org/10.1016/j.ijantimicag.2007.06.024

[42] Nilsson, A.C., Björkman, P., Welinder-Olsson, C., Widell, A. and Persson, K. (2010) Clinical Severity of Mycoplasma pneumoniae (MP) Infection Is Associated with Bacterial Load in Oropharyngeal Secretions But Not with MP Genotype. BMC Infectious Diseases, 10, 39. https://doi.org/10.1186/1471-2334-10-39

[43] Swanson, S.J., Neitzel, D., Reed, K.D. and Belongia, E.A. (2006) Coinfections Acquired from Ixodes Ticks. Clinical Microbiology Reviews, 19, 708-727. https://doi.org/10.1128/CMR.00011-06

[44] Levin, M.L. and Fish, D. (2001) Interference between the Agents of Lyme Disease and Human Granulocytic Ehrlichiosis in a Natural Reservoir Host. Vector-Borne and Zoonotic Diseases, 1, 139-148. https://doi.org/10.1089/153036601316977741 